\title{
TANGGUNG JAWAB AGEN DISTRIBUTOR ATAS PEREDARAN OBAT KUAT IMPORT TANPA IZIN EDAR DITINJAU DARI UNDANG- UNDANG PERLINDUNGAN KONSUMEN
}

\author{
Septyani Roby Hartanty \\ (Mahasiswa Program S1 Fakultas Hukum Universitas Tarumanagara) \\ (E-mail: qnoythea136@gmail.com)
}

Dr. Susanti Adi Nugroho, S. H., M. H

(Corresponding Author)

(Dosen Fakultas Hukum Universitas Tarumanagara. Meraih Sarjana Hukum pada Fakultas Hukum Universitas UNDIP, Magister Hukum pada Fakultas Hukum Universitas UPH, Doktor (Dr.) pada Fakultas Hukum Universitas UNPAD)

(E-mail: susanti_nugroho@yahoo.com)

\begin{abstract}
Law Number 8 of 1999 about Consumer Protection on this matter covers consumer rights and business responsibilities. This study discusses the responsibility for efforts made to fulfill customer rights for information and benefits of imported drugs without marketing permits and also related to licensing regarding permits for consumers who need funds for imported drugs. Legal protection for consumers of illegal drugs carried out by the government through the Food and Drug Supervisory Agency (BPOM). With the presence of BPOM, the government has supervised. Employers are responsible for the makers of goods because they carry out imported goods or official importers. Therefore, businesses that represent individuals must be responsible for losses that arise only as importers not as producers of these goods. Therefore, the legal basis that can be requested by consumers as a form of accountability proposed for drug business assistance is court punishment as regulated by article 62 paragraph 1 of the UUPK. This study gives an appeal to the public to be more careful in taking medicines should be on the advice of a doctor or pharmacist and should not be tempted easily by the promotions offered because drugs containing BKO can be used.
\end{abstract}

Keywords : Consumer Protection, Strong Drug For Illegal Imports, Responsibility Of Distributor Agents. 


\section{PENDAHULUAN}

\section{A. Latar Belakang}

Pembukaan Undang-Undang dasar 1945 (UUD 45) menegaskan tujuan pembentukan Negara Republik Indonesia ialah terwujudnya masyarakat Indonesia yang sejahtera, adil dan makmur. Pada alinea ke-4 UUD tahun 1945 yang berbunyi, "Kemudian dari pada itu untuk membentuk suatu Pemerintah Negara Indonesia yang melindungi segenap bangsa Indonesia dan seluruh tumpah darah Indonesia dan untuk memajukan kesejahteraan umum, mencerdaskan kehidupan bangsa dan ikut serta melaksanakan ketertiban dunia yang berdasarkan kemerdekaan, perdamaian abadi dan keadilan sosial maka disusunlah kemerdekaan kebangsaan Indonesia itu dalam suatu Undang-Undang Dasar Negara Indonesia yang terbentuk dalam suatu susunan Negara Republik Indonesia yang berkedaulatan rakyat dengan berdasarkan kepada ketuhanan Yang Maha Esa, kemanusiaan yang adil dan beradab, persatuan Indonesia dan kerakyatan yang dipimpin oleh hikmat kebijaksanaan dalam permusyawaratan/perwakilan, serta dengan mewujudkan suatu keadilan sosial bagi seluruh rakyat Indonesia”.

Pada alinea ke-4 UUD tahun 1945 menyatakan secara jelas bahwa Indonesia sebagai Negara merdeka yang berdasarkan hukum menyatakan dukungan serta usahanya untuk mewujudkan kesejahteraan umum, mencerdaskan kehidupan bangsa dan ikut melaksanakan ketertiban dunia yang berdasarkan kemerdekaan, perdamaian abadi dan keadilan sosial bagi seluruh rakyat Indonesia. Di dalam Sistem Kesehatan Nasional disebutkan bahwa kesehatan menyangkut semua segi kehidupan yang ruang lingkup dan jangkauannya sangat luas. Hal tersebut sejalan dengan pengertian kesehatan yang diberikan oleh dunia internasional sebagai: $A$ state of complete physical, mental and social, well being and not merely the absence of desease or infirmity yang berarti suatu negara yang sudah 
mapan secara fisik, mental dan sosial tidak sepenuhnya bebas dari masalah kesehatan dan kelemahan-kelemahan-kelemahannya. ${ }^{1}$

Pasal 111 Undang-Undang Nomor 36 Tahun 2009 tentang Kesehatan (UU Kesehatan) telah mengatur tentang pangan yang layak untuk beredar yakni setiap makanan dan minuman yang akan diberi izin edar harus memenuhi standardisasi dan keamanan pangan khususnya persyaratan kesehatan. Pemerintah juga telah menetapkan obat, bahan obat, obat tradisional, kosmetika dan alat kesehatan hanya dapat diedarkan setelah mendapat izin edar pasal 106 UU Kesehatan tahun 2009. Larangan untuk mengedarkan obat-obatan bagi pelaku usaha yang tidak memiliki keahlian dan kewenangan juga diatur dalam ketentuan Pasal 98 ayat (2) Undang-Undang Nomor 36 tahun 2009 tentang Kesehatan. Selain itu minuman dan makanan yang dikemas wajib diberikan tanda atau label sesuai Peraturan Pemerintah tentang Label dan Iklan Pangan. Namun konsumen tidak tahu apakah nomor registrasi yang dicantumkan dalam kemasan produk tersebut benar dikeluarkan oleh BPOM atau Dinas Kesehatan.

Untuk dapat menjamin penyelanggaran perlindungan konsumen yang adil, maka Negara Indonesia mencangkup perlindungan konsumen dalam suatu produk hukum. Hal tersebut sangat penting karena hanya hukum yang memiliki kekuatan untuk memaksa pelaku usaha untuk mematuhinya, dan juga hukum memiliki sanksi yang tegas. Meningkatnya pelaku usaha dikarenakan oleh penguasaan produk yang sepenuhnya berada ditangan produsen. Upaya pemerintah untuk memberikan jaminan perlindungan kepada para konsumen didasari atas situasi yang tidak kondusif, hal ini merupakan faktor penting diberlakukannya Undang-undang Nomor 8 Tahun 1999 tentang Perlindungan Konsumen (UUPK). Jauh sebelum diberlakukannya UUPK, secara hukum formal prinsip product liability sebenarnya telah diatur dalam beberapa pasal dalam KUH Perdata, diantaranya Pasal

\footnotetext{
${ }^{1}$ Bahder Nasution, Sistem Hukum, (Jakarta: PT Rineka Cipta, 2005) hal. 1.
} 
1322, 1473, 1474, 1491, 1504 sampai dengan 1511. Walaupun dengan catatan, ruang lingkup materinya tidak menjangkau secara luas ketentuan yang diatur dalam UUPK. Pada KUHPerdata secara umum apabila ada seorang yang melakukan perbuatan melawan hukum (PMH) maka seseorang tersebut diwajibkan untuk memberikan ganti kerugian. Kesulitan yang dialami pihak konsumen yakni harus membuktikan adanya unsur kesalahan yang dilakukan oleh pihak pelaku usaha agar gugatan konsumen tidak gugur/batal.

Tanggung jawab produk menurut buku III KUH Perdata adalah tanggung jawab produk dari sudut hukum perikatan terdiri dari dua macam diantaranya: (a) tanggung jawab produk secara kontraktual dan (b) tanggung jawab produk secara deliktual. Undang-Undang Perlindungan Konsumen telah mengatur tentang product liability, namun dalam pelaksanaannya kurang efektif dalam melindungi hak-hak konsumen dari kerugian yang diakibatkan oleh suatu produk. Oleh karena itu dalam rangka dilakukannya amandemen UUPK, masalah strict liability menjadi konsep penting dan relevan untuk didiskusikan. Prinsip tanggung jawab mutlak (strict liability) itu sendiri dapat diartikan bahwa pelaku usaha harus bertanggung jawab atas kerugian konsumen tanpa harus membuktikan ada tidaknya kesalahan pada dirinya. Pasal 7 huruf (a) UUPK, menegaskan salah satu kewajiban bagi para pelaku usaha yaitu harus beriktikad baik dalam melakukan usahanya, maka tidak dibenarkan mencampurkan bahan kimia pada produk pangan yang dapat membahayakan kesehatan konsumen.

Dalam pasar bebas dan persaingan global hanya pelaku usaha handal lah yang dapat menghasilkan barang dan/atau jasa serta mempunyai daya saing yang tinggi didalam ataupun diluar negeri. Akan tetapi perdagangan pasar bebas lebih cenderung dapat mengakibatkan barang dan/atau jasa yang beredar belum tentu terjamin keamanan, kesehatan dan juga keselamatan konsumen. Kondisi yang demikian pada satu pihak sangat bermanfaat bagi kepentingan konsumen karena 
kebutuhan konsumen akan barang dan/atau jasa yang diinginkan dapat terpenuhi serta semakin terbuka lebarnya kebebasan untuk memilih aneka jenis kualitas barang dan/atau jasa yang sesuai dengan keinginan dan kemampuan konsumen. ${ }^{2}$ Beredarnya obat kuat impor tanpa izin dapat mengancam kesehatan dan keselamtan konsumen, yang dapat mengakibatkan kerugian di dalam kehidupan masyarakat secara luas. Obat-obatan merupakan produk yang dikonsumsi oleh masyarakat dan mempunyai nilai yang sangat penting sebagai sebuah produk kesehatan karena obat dapat menyebuhkan penyakit yang diderita oleh seseorang.

Akhir-akhir ini sering diberitakan diberbagai media masa bahwa banyak produk obat kuat impor atau obat penambah vitalitas yang berderar, ternyata mengandung bahan-bahan yang berbahaya bagi kesehatan. Diketahui pula bahwa sebagian produk obat kuat impor tersebut belum terdaftar pada Badan Pengawas Obat dan Makanan, sehingga ketika konsumen mendapat masalah akibat pemakaian produk tersebut tidak dapat menuntut pertanggungjawaban pelaku usaha ataupun importir produk tersebut sebagai pihak yang bertanggung jawab. Seperti contoh kasus Pengadilan Negeri Kediri, Khoirul Anam lelaki 21th mengedarkan obat yang belum mendapatkan izin edar digrebek Satres Polres Kediri Kota karna pihak kepolisian mendapatkan pengaduan dari masyarakat sekitar bahwa didalam toko milik tersangka menjual obatobatan yang sebagian besar tidak memiliki izin edar dari BPOM. ${ }^{3}$ Berikut daftar nama obat ilegal yang diedarkan tablet obat kuat untuk sexual merk (levitra, V6, stud, playboy, maxman, viagra, maximum powerfull, viagra china, pil chien chin), kapsul obat kuat untuk sexual merk (lianza, nangen), cairan untuk memperbesar alat vital pada pria dengan merk (lintah oil, minyak bulus, cobra oil), cairan perangsang sexual merk

${ }^{2}$ Susanti Adi Nugroho, Proses Penyelesaian Sengketa Konsumen Ditinjau dari Hukum Acara Serta Kendala Implementasinya, cetakan ke-1, (Jakarta: Kencana, 20008), 1.

3 Didik Mashudi, Toko Obat Kuat Tanpa Izin Digrebek Polisi, diakses dari http://m.tribunnews.com/regional/2012/12/13/toko-obat-kuat-tanpa-izin-digrebek-polisi, , pada tanggal 15 Maret 2018 pukul 20.15. 
(american viagra), cairan obat kuat untuk sexual merk (procomil spray), perangsang sexual berbentuk serbuk dengan (merk xibanyacangyingfen), perangsang sexual berbentuk cairan dengan merk (set drops). Produk obat diatas mengandung bahan berbahaya seperti sildelnafil citrate atau tadalafil atau vardenafil, yang seharusnya diberikan oleh dokter khusus kepada pasien/orang yang mengalami gangguan atau penderita Disfungsi Ereksi (DE).

Kandungan pada obat ilegal bukan hanya berdampak buruk pada kesehatan tubuh tetapi juga berdampak pada kematian seperti pada kasus obat kuat import yang telah menewaskan seorang pria paruh baya, Slamet Mulyadi tewas ketika hendak berhubungan badan dengan PSK di kawasan lokalisasi terselubung dijalan Diponegoro, Kecamatan Tambun Selatan, Kabupaten Bekasi. ${ }^{4}$ Efek samping yang dialami setelah mengkonsumsi obat ilegal tersebut pada awal pemakaian konsumen merasa terdapat perubahan vitalitas yang semakin bertambah, namun ternyata setelah memakai dalam jangka waktu lama dapat menimbulkan ketergantungan yang berakibat penambahan dosis, sehingga kelebihan dosis pemakaian yang mengakibatkan sakit kepala, mual, kulit mengelupas, gangguan pencernaan, gangguan pengliahatan, gangguan pendengaran, radang hidung, nyeri dada, nyeri otot, muka memerah, palpitasi (denyut jantung menjadi lebih cepat), potensi seks hilang secara permanen, dan bahkan mengakibatkan kematian.

\section{B. Perumusan Masalah}

Bagaimana pertanggungjawaban agen distributor apabila terdapat konsumen yang mengalami kerugian akibat mengkonsumsi obat kuat import tanpa izin edar?

${ }^{4}$ Adi Nugroho, Diduga overdosis obat kuat, pria paruh baya Bekasi tewas dikamar PSK, diakses dari http://m.merdeka.com/peristiwa/diduga-overdosis-obat-kuat-pria-paruh-baya-bekasitewas-di-kamar-psk.html, pada tanggal 03 Agustus 2018 pukul 19.57. 


\section{Metode Penelitian}

Tipe penelitian megunakan penelitian hukum normatif (Legal Reserch) adalah penelitian yang dilakukan untuk menemukan kebenaran koherensi yakni adakah aturan hukum sesuai norma hukum dan adakah norma yang berupa perintah atau larangan yang sesuai dengan prinsip hukum, serta apakah tindakan (act) seseorang sesuai dengan norma hukum (bukan hanya sesuai aturan hukum) atau prinsip hukum. ${ }^{5}$ Alasan menggunakan tipe penelitian normatif ini dikarenakan penelitian ini dilakukan dengan cara menggambarkan suatu permasalahan lalu menganalisa permasalahan tersebut melalui sumber-sumber data yang telah dikumpulkan kemudian disusun serta diolah dengan berlandaskan kepada konsep-konsep dan teori yang berkaitan dengan penelitian tersebut. Bahan-bahan hukum primer yang digunakan diantaranya catatan-catatan resmi atau risalah dalam pembuatan perundangundangan, perundang-undangan dan putusan-putusan hakim. ${ }^{6}$ Bahanbahan hukum sekunder menggunakan buku-buku produk hukum termasuk tesis, skripsi, jurnal hukum dan disertasi hukum. Sedangkan bahan hukum tersier menggunakan studi pustaka dan wawancara. Spesifikasi penelitian menggunakan penelitian analisis yakni dengan penelitian yang menggambarkan peraturan perundang-undangan yang berlaku dikaitkan dengan teori-teori hukum positif yang menyangkut permasalahan yang sedang diteliti. ${ }^{7}$

\section{PEMBAHASAN}

\section{A. Posisi Kasus}

Ratusan obat kuat impor ilegal asal China termasuk alat bantu sex dan krim pemutih berbahaya telah disita pihak Kepolisian Republik

${ }^{5}$ Peter Mahmud Marzuki, Penelitian Hukum, (Jakarta: Kencana Prenada Media Group, 2005), hal. 47.

${ }^{6}$ Ibid., hal. 181.

7 Soemitro Ronny Hanitijo, Metode Penelitian Hukum dan Yurimetri, (Jakarta: Ghalia Indonesia, 1988), hal. 11. 
Indonesia. Hal tersebut diketahui setelah Satreskrim Polres Kediri Kota melakukan penggerebekan didaerah Jalan HOS Cokroaminoto, Kota Kediri, Jawa Timur Kamis (13/12/2012). Dalam penggeledahan tersebut ditetapkan dua orang tersangka yang mengelola toko yakni Miftahul Huda berusia 27 tahun dan Khoirul Anam berusia 21 tahun keduanya merupakan warga Demak Jawa tengah. Dari hasil penggeledahan tersebut, pihak kepolisian telah menemukan dan menyita barang bukti berupa ratusan ribu obat kuat impor, alat bantu sex, krim pemutih dan obat-obatan pelangsing yang belum memiliki izin edar dari BPOM dan tidak terdaftar di Depkes RI sehingga sangat diragukan keasliannya. ${ }^{8}$ Penggeledahan tersebut dilakukan berdasarkan hasil laporan dari warga masyarakat sekitar, yang merasakan kecurigaan terhadap toko tersebut, yang kemudian ditindak lanjuti oleh pihak kepolisian. Dari hasil pengembangan penyidikan, pihak kepolisian memperoleh informasi bahwa obat tersebut didapatkan dari pemasoknya yang berada di daerah Jakarta.

Menurut hasil keterangan yang diperoleh, dapat diketahui bahwa tersangka telah menjalankan jenis usaha yang dilarang tersebut sudah 10 bulan terakhir yakni berupa aneka jenis produk obat-obatan penambah stamina pria, alat bantu sex, obat pelangsing dan krim pemutih kulit yang dijual di Kota Kediri. Toko tersebut menual obat-obatan berbagai jenis mulai dari pil, salep, lotion dan krim yang diimpor dari Cina. Pembeli yang sering mendatangi tokonya biasanya merupakan suami istri, lelaki yang memiliki gangguan pada organ intimnya atau laki-laki yang berusia diatas 40 tahun sedangkan untuk penjualan krim pemutih dan obat pelangsing kebanyakan adalah ibu-ibu rumah tangga dan remaja. Penjualan animo yang paling laris karna menurut pengakuan para pelanggan yang sering membeli ditoko tersebut khasiat dari obat cukup

8 Didik Mashudi, Toko Obat Kuat Tanpa Izin Digrebek Polisi, diakses dari http://m.tribunnews.com/regional/2012/12/13/toko-obat-kuat-tanpa-izin-digrebek-polisi, pada tanggal 15 Maret 2018 pukul 20.00. 
bagus karena hampir setiap hari banyak yang membelinya. Menurut pengakuan dari tersangka bahwa memang benar tersangka belum memiliki surat izin usaha dan surat izin edar dari pihak yang berwenang, pada saat diperiksa penyidik Satreskrim Polres Kediri Kota tersangka mengaku baru akan mengajukan pembuatan surat izin akan tetapi sudah keburu diamankan oleh pihak yang berwajib.

Satreskrim Polres Kediri Kota menyatakan bahwa obat yang telah diedarkan oleh tersangka termasuk dalam kategori golongan obat keras. Selain tidak dilengkapi dengan izin edar obat kuat impor yang diedarkan oleh tersangka tergolong obat yang berbahaya. Apabila dikonsumsi maka dapat menimbulkan efek samping seperti mual, radang pernafasan, nyeri, bahkan obat kuat impor tersebut juga dapat mengakibatkan kematian. Selanjutnya dari keterangan yang diakui oleh tersangka bahwa ratusan ribu obat kuat impor tersebut berasal dari China yang diperolehnya melalui pemasok yang berada di Jakarta. Hingga saat ini pihak kepolisian sedang menyelidiki keterangan akan informasi yang diperoleh dari tersangka mengenai pemasok obat kuat import ilegal tersebut. Adapun barang bukti obat kuat import yang disita terdiri atas 19 (sembilan betas) jenis, antara lain: capsul obat kuat untuk sexual merk LIANZA sebanyak 2 (dua)kotak, tablet obat kuat untuk sexual merk LEVITRA sebanyak 2 (dua) kotak, tablet obat kuat untuk sexual merk V6 sebanyak 1 (satu) kotak, tablet obat kuat untuk sexual merk STUD sebanyak 1(satu) kotak, tablet obat kuat untuk sexual merk PLAY BOY sebanyak 1 (satu) kotak, cairan untuk memperbesar alat vital pada pria dengan merk LINTAH OIL sebanyak 7 (tujuh) kotak, cairan untuk memperbesar alat vital pria dengan merk MINYAK BULUS sebanyak 14 (empat betas) kotak, tablet obat kuat untuk sexual merk MAXMAN sebanyak 5 (lima) kotak, tablet obat kuat untuk sexual merk VIAGRA (100 Mg) sebanyak 3 (tiga) kotak, cairan untuk memperbesar alat vital pada pria merk COBRA OIL sebanyak 3 (tiga) kotak, cairan perangsang sexual merk AMERICAN VIAGRA sebanyak 1 (satu) kotak, tablek obat kuat untuk sexual merk 
MAXIMUM POWERFULL sebanyak 1 (satu) kotak, capsul obat kuat untuk sexual merk NANGEN sebanyak 1 (satu) kotak, cairan obat kuat untuk sexual merk PROCOMIL SPRAY sebanyak1 (satu) kotak, tablet obat kuat untuk sexual merk VIAGRA CHINA sebanyak 1 (satu) kotak, perangsang sexual berbentuk serbuk dengan merk XIBANYACANGYINGFEN sebanyak 1 (satu) pak, perangsang sexual berbentuk cairan dengan merk SET DROPS sebanyak 1 (satu) kotak, obat kuat untuk sexual merk VIAGRA buatan America sebanyak 2 (dua) kotak, pil CHIEN CHIN sebanyak 1 (satu) kotak.

Barang-barang jenis kosmetika sebanyak 21 (dua puluh satu) jenis, antara lain:capsul pelangsing dengan merk FRUIT PLANS sebanyak 5 (lima) kotak, cream untuk menghilangkan bekas luka merk MEILIBAHENLING sebanyak 5 (lima) kotak, pelangsing bentuk cream merk GREEN TEA sebanyak 1 (satu) kotak, cream pembersih wajah bertuliskan Whitening \& De-Specking Cleanser sebanyak 1 (satu) kotak, kapsul untuk peninggi badan merk GROW-UP ukuran kec it seebanyak 1 (satu) kotak, kapsul untuk peninggi badan merk GROW-UP ukuran besar 1 (satu) kotak, lotion untuk memperbesar payudara dengan merk HUOMEIREN sebanyak 3 (tiga) kotak, cairan penumbuh rambut merk MIRACLE SERUM sebanyak 1 (satu) kotak, obat Pelangsing tubuh merk ACAI BERRY sebanyak 2 (dua) kotak, pemerah bibir merk QUEEN 1 sebanyak 1 (satu) kotak, pemutih badan merk EMILAY sebanyak 2 (dua) botol, cream pemutih wajah bertuliskan Genuine sebanyak 1 (satu) kotak, cream pemutih wajah merk TENSUNG sebanyak 1 (satu) kotak, cairan Perontok bulu merk IVONI OIL sebanyak 4 (empat) kotak, kapsul untuk memperbesar payudara merk ENIKONG sebanyak 1 (satu) botol, cairan untuk memperbesar payudara merk MEI YI SHENG sebanyak 1 (satu) botol, crem lulur TENING DESPECKING CLEANER merk KEIZO sebanyak 1 (satu) kotak, pelangsing badan merk FATLOSS sebanyak 3 (tiga) kotak, kapsul penggemuk badan merk GINSENG KIANPI PIL sebanyak 1 (satu) 
kotak, kapsul pengemuk badan merk SUPER GINSENG KIANPI PIL sebanyak 1 (satu) kotak, kapsul penghilang jerawat merk AN CHANG WAN sebanyak 1 (satu) kotak. ${ }^{9}$

\section{B. Bentuk-Bentuk Pelanggaran Yang Dilakukan Pelaku Usaha}

Sebelum membahas mengenai pertanggungjawaban yang dapat dimintakan kepada pelaku usaha obat kuat impor, maka akan dibahas terlebih dahulu pelanggaran-pelanggaran hukum yang telah dilakukan oleh pelaku usaha dalam pendistribusian obat kuat impor. Pelaku usaha telah melanggar beberapa peraturan perundang-undangan diantaranya:

1. Berdasarkan Undang-Undang Nomor 8 Tahun 1999 Tentang Perlindungan Konsumen, bahwa pelaku usaha telah melanggar beberapa ketentuan pasal di dalam UUPK, diantaranya:

a. Melanggar hak-hak dari konsumen atas keamanan, kenyamanan dan keselamatan dalam mengkonsumsi barang, mendapat hak atas informasi yang benar, jelas dan jujur mengenai kondisi barang berdasarkan ketentuan Pasal 4 huruf a dan c UUPK. ${ }^{10}$ Pelaku usaha sebagai pedagang eceran obat sudah sangat jelas mengetahui bahwa obat kuat impor yang mengandung zat aktif BKO dan diperdagangkan tersebut dapat membahayakan kesehatan bahkan keselamatan konsumen, sehingga konsumen dapat merasa tidak nyaman karena produk tersebut tidak aman untuk digunakan. Dengan demikian, pelaku usaha yang mendistribusikan dan mengecerkan obat kuat impor yang mengandung zat aktif BKO telah melanggar hak konsumen untuk mendapatkan keamanan dalam mengkonsumsi obat. Kemudian dalam mempromosikan obat kuat impor yang mengandung zat aktif BKO ini, pelaku usaha tidak memberikan

\footnotetext{
9 Putusan Mahkamah Agung Republik Indonesia Putusan Nomor: 33/Pid.Sus/2013/PN.Kdr.

10 Indonesia, Kitab Undang-Undang Nomor 8 Tahun 1999 tentang Perlindungan Konsumen, (Jakarta: Pradnya Paramita, 2004), Pasal. 4.
} 
informasi yang jelas, benar dan jujur mengenai kandungan dan efek samping dari obat kuat impor tersebut, akan tetapi pelaku usaha memberikan promosi yang berlebihan dalam mengiklankan produk yang dijualnya. Dengan demikian, pelaku usaha juga telah melanggar hak konsumen untuk mendapatkan informasi yang benar mengenai manfaat serta kondisi barang.

b. Pelaku usaha melanggar kewajiban untuk beritikad baik, dengan tidak memberikan informasi yang jujur, jelas dan benar akan kondisi barang, serta dalam menjamin kualitas mutu barang yang di distribusikan atau diperdagangkan tidak sesuai ketentuan Pasal 7 huruf a, b, dan d UUPK. ${ }^{11}$ Pelaku usaha yang jelas telah mengetahui adanya kandungan zat aktif BKO dari obat kuat impor yang dijualnya kepada konsumen. Dengan demikian pelaku usaha telah melanggar kewajibannya untuk beritikad baik dalam melakukankan usahanya tersebut. Kemudian, pelaku usaha juga tidak memberikan kejelasan mengenai jaminan akibat dari pemakaian obat kuat impor yang dijualnya. Dengan demikian pelaku usaha telah melanggar kewajibannya untuk memberikan jaminan atas produk barang yang dijualnya kepada konsumen. Berikutnya, pelaku usaha tidak menjamin mutu obat yang diperdagangkannya atau di distribusikan dengan menyampaikan informasi yang tidak sesuai dengan kenyataan dan tidak jujur mengenai kandungan zat aktif BKO tersebut. Dengan demikian pelaku usaha menunjukan suatu pelanggaran dari kewajibannya dalam menjalankan usahanya.

c. Melanggar perbuatan yang dilarang dengan memperdagangkan produk/barang yang tidak sesuai dengan manfaat dan kegunaannya yang tertera dalam kemasan produk pada keterangan barang dan tidak sesuai dengan fakta yang 
diinformasikan dalam promosi atau iklan penjualan produk tersebut dan juga tidak menyertakan informasi atau petunjuk yang menggunakan bahasa Indonesia, berdasarkan Pasal 8 ayat (1) huruf d, e, f dan j Undang-Undang Perlindungan Konsumen. ${ }^{12}$ Produsen mengetahui bahwa obat kuat impor yang diperdagangkan tidak memiliki izin edar akan tetapi pelaku usaha tersebut tetap memperjual belikan produk tanpa mengutamakan kesehatan dan keselamatan konsumen tersebut. Oleh sebab itu, produk barang yang diperdagangkan tidak sesuai dengan manfaat dari penggunaan tertentu yang diinformasikan dalam keterangan produk. produsen juga telah melanggar perbuatan yang dilarang dengan tidak mencantumkan informasi atau petunjuk yang sesuai. Hal tersebut dapat ditemukan pada setiap obat kuat impor yang beredar, sebagaimana yang tertera pada kemasan obat-obatan tersebut merupakan bahasa asing yang sulit dapat dimengerti oleh konsumen, bahkan para pelaku usaha atau pedagang eceran obat yang mengedarkannya kesulitan untuk dapat memahami ataupun mengerti dari berbagai macam jenis bahasa, baik dalam bentuk bahasa Inggris, Jerman, bahkan China yang terdapat pada kemasan obat tersebut.

d. Melanggar perbuatan yang dilarang dengan menawarkan dan mengiklankan barang secara tidak benar bahwa seolah-olah produk tersebut telah memiliki sponsor untuk menarik minat konsumen dan juga pelaku usaha secara langsung menggunakan kata-kata yang berlebihan untuk menarik perhatian para konsumen, seperti tidak mengandung efek samping dan resiko, aman dan tidak berbahaya tanpa disertai keterangan yang lengkap dan jelas, dan juga pelaku usaha menawarkan janji-janji manis yang belum pasti kebenaran khasiatnya, berdasarkan

${ }^{12}$ Ibid., Pasal 8. 
ketentuan Pasal 9 huruf c, i, dan k UUPK. ${ }^{13}$ Pelaku usaha telah mengetahui bahwa obat impor yang diperdagangkan tidak mendapatkan dukungan sponsor dari PBF, akan tetapi para pelaku usaha tersebut tetap memuat nama PBF, seperti Pfizer, Eli Lilly and Company, dan Bayer HealthCare Pharmaceuticals pada papan reklame di toko atau sarana yang mereka gunakan dalam memperdagangkan obat kuat impor tersebut, sebagaimana pada kenyataannya bahwa PBF hanya mendistribusikan produk barangnya hanya pada apotek besar dan yang mempunyai izin edar obat. Kemudian, pelaku usaha juga menggunakan kata-kata "aman", "ampuh", dan "terbukti" yang dimuat pada papan reklame di setiap toko atau sarana yang digunakan, tanpa keterangan efek samping yang lengkap. Hal tersebut juga di dukung oleh karena pelaku usaha melakukan suatu perbuatan yang telah dilarang dengan memberikan janji yang belum pasti kepada konsumen bahwa obat kuat impor tersebut mampu membuat "tahan lama" atau mampu mengatasi "ejakulasi dini" yang dinyatakan dalam promosi atau iklan penjualan barang.

e. Melanggar perbuatan yang dilarang dengan menawarkan barang untuk diperjual-belikan dengan cara mempromosikan, mengiklankan atau membuat suatu pernyataan yang tidak sesuai dengan kenyataan atau menyesatkan mengenai manfaat suatu produk dan bahaya penggunaan produk, berdasarkan ketentuan Pasal 10 huruf c, i, dan k UUPK. ${ }^{14}$ Pelaku usaha jelas telah mengetahui bahwa obat kuat impor yang mengandung zat aktif BKO dapat digolongkan sebagai obat keras, karena untuk mendapatkannya konsumen harus terlebih dahulu berkonsultasi dengan dokter yang akan memberikan resep yang sesuai dengan dosis yang diperlukan. Hal tersebut dikarenakan obat kuat impor

\footnotetext{
13 Ibid., Pasal 9.

${ }^{14}$ Ibid., Pasal 10.
} 
yang mengandung zat aktif BKO yang dapat menimbulkan efek samping terhadap konsumen yang memiliki kondisi kesehatan tertentu, sehingga apabila digunakan secara tidak berhati-hati dan menurut kegunaannya, maka dapat menimbulkan efek yang berbahaya bagi konsumen yang mengkonsumsinya. Dengan demikian, penawaran obat kuat impor tanpa adanya informasi yang benar atau jujur dari pelaku usaha mengenai kandungan obat kuat impor tersebut, merupakan suatu bentuk penawaran produk barang dengan membuat suatu pernyataan yang tidak benar tentang bahaya penggunaannya.

2. Berdasarkan Undang-Undang Nomor 36 Tahun 2009 Tentang Kesehatan. Pelaku usaha telah melanggar beberapa ketentuan pasal di dalam UU Kesehatan, antara lain:

a. Melanggar perbuatan yang dilarang dengan menyimpan, mempromosikan, dan mengedarkan obat kuat impor dengan tidak memiliki keahlian dan kewenangan dalam sediaan farmasi, berdasarkan ketentuan Pasal 98 ayat (2) UU Kesehatan. ${ }^{15}$ Pelaku usaha atau pedagang eceran obat sangat jelas mengetahui bahwa dalam memperdagangkan obat tersebut tidak memiliki keahlian sebagai apoteker dan kewenangan mempunyai izin edar obat, serta dilarang untuk menyimpan, mempromosikan, dan mengedarkan obat kuat impor yang diperdagangkannya.

b. Melanggar sediaan farmasi yang hanya dapat diedarkan setelah mendapat izin edar, dan juga dalam hal informasi sediaan farmasi yang harus memenuhi syarat obyektivitas dan kelengkapan serta tidak menyesatkan, berdasarkan ketentuan Pasal 106 ayat (1) dan ayat (2) UU Kesehatan. ${ }^{16}$ Pelaku usaha atau pedagang eceran obat sudah sangat jelas mengetahui bahwa tidak memiliki izin edar dalam memperdagangkan obat kuat

\footnotetext{
15 Ibid., Passl 98 ayat (2).
}

${ }^{16}$ Ibid., Pasal 106 ayat (2). 
impor yang diperdagangkannya. Selain itu, pelaku usaha juga tidak memberikan informasi yang benar kepada konsumen mengenai obat kuat impor yang diperdagangkannya melalui obyektivitas dan kelengkapan pada kemasan, akan tetapi memberikan informasi yang menyesatkan dari iklan/reklame yang dipasang pada sarana dengan memuat kalimat janji yang belum pasti. Pada saat ini semakin banyak obat kuat impor yang mengandung zat aktif BKO beredar di pasaran. Oleh karena itu, informasi tentang produk obat kuat impor yang tertera pada promosi dan iklan juga harus sesuai dengan manfaat dan kegunaan yang sesuai dengan kenyataan yang ada, lengkap dengan mencantumkan khasiat, efek samping, pantangannya, kontra indikasi serta tidak boleh menyesatkan atau informasi tentang obat kuat impor tersebut harus akurat, jujur, bertanggungjawab dan tidak boleh menimbulkan rasa kekhawatiran kepada konsumen akan masalah kesehatan.

3. Berdasarkan Keputusan Menteri Kesehatan Nomor 1331/MENKES/SK/X/2002 tahun 2002 tentang Pedagang Eceran Obat. Pelaku usaha telah melakukan pelanggaran atas ketentuan yang mengatur bahwa pedagang eceran obat harus menjanin bahwa obat-obat yang dijual bermutu baik serta berkualitas dan berasal dari pabrik farmasi atau pedagang besar farmasi yang telah mendapat izin dari Departemen Kesehatan dan juga melanggar ketentuan yang mengatur bahwa setiap pengecer obat wajib mempekerjakan seorang asisten apoteker sebagai penaggungjawab dari farmasi, berdasarkan ketentuan Pasal 2 ayat (2) dan Pasal 4 Kepmenkes Nomor 1331 tahun 2002 tentang Pedagang Eceran Obat. ${ }^{17}$ Pedagang eceran obat sebagai pelaku usaha sudah sangat jelas mengetahui bahwa dalam memperdagangkan obat kuat impor tidak berasal dari pabrik farmasi

${ }^{17}$ Keputusan Menteri Kesehatan Nomor 1331/MENKES/SK/X/2002 tahun 2002 tentang Pedagang Eceran Obat Pasal 2 ayat (2). 
atau PBF yang sudah jelas mendapatkan izin dari Menteri Kesehatan, sehingga obat-obatan yang dijualnya tidak bermutu baik. Kemudian, produsen juga telah mengetahui bahwa tidak mempunyai keahlian sebagai apoteker ataupun dengan mempekerjakan seorang asisten apoteker sebagai penanggungjawab farmasi dalam memperdagangkan obat kuat impor tersebut.

\section{Peraturan Kepala Badan Pengawas Obat dan Makanan Republik Indonesia Nomor HK.00.05.1.3459 tentang Pengawasan Pemasukan Obat Impor}

Pelaku usaha telah melakukan pelanggaran mengenai ketentuan yang mengatur bahwa yang berhak memasukan obat import ke dalam wilayah Indonesia yaitu PBF atau industri farmasi sebagai pendaftar resmi yang sah dan telah memiliki izin edar atas obat impor dan harus mendapatkan persetujuan untuk pemasokan obat impor dari Kepala BPOM, berdasarkan ketentuan Pasal 2 dan Pasal 3 Peraturan Kepala BPOM Nomor HK.00.05.1.3459 tentang Pengawasan Pemasukan Obat Impor. Pelaku usaha jelas telah mengetahui bahwa yang bersangkutan hanya sebagai pedagang eceran obat yang belum terdaftar dan tidak mendapatkan izin edar atas obat impor dari Kepala BPOM, karena yang berhak memasukan obat impor hanya pedagang besar farmasi atau industri farmasi yang memiliki agen atau kantor perwakilannya di wilayah Indonesia. Kemudian pelaku usaha juga melakukan pelanggaran dengan menyelundupkan obat kuat impor karena tidak terdaftar dan tidak memiliki izin edar, yang mana pelaku usaha sebelum mengimpor obatobatan tersebut harus terlebih dahulu mendapatkan persetujuan pemasokan obat impor dari Kepala BPOM. Dengan demikian pelaku usaha menunjukan suatu pelanggaran mengenai izin edar obat dan persetujuan pemasokan obat impor ke wilayah Indonesia dalam kegiatan usahanya. 


\section{Pelaku Usaha yang Bertanggung Jawab Terhadap Konsumen}

Banyaknya pedagang eceran produk obat kuat impor yang tidak memiliki agen distributor ataupun kantor perwakilan di Indonesia memicu timbulnya permasalahan mengenai pelaku usaha mana yang bertanggung jawab terhadap konsumen yang mengalami kerugian akibat mengkonsumsi obat kuat tersebut. Mengenai Pelaku Usaha yang bertanggung jawab terhadap konsumen yang mengalami kerugian akibat mengkonsumsi obat Kuat Impor yaitu apabila pelaku usaha dan importir memiliki izin usaha atau importir legal maka yang bertanggung jawab atas keaslian produk tersebut adalah pelaku usaha atau importir resmi tersebut, jika pelaku usaha maupun importir itu ilegal atau tidak memiliki izin usaha maka yang bertanggung jawab adalah pengecernya. ${ }^{18}$ Pengaturan dalam ketentuan Pasal 21 ayat (1) UUPK, maka importir barang bertanggung jawab sebagai pembuat barang yang diimpor apabila importasi barang tersebut tidak dilakukan oleh agen atau perwakilan produsen luar negeri, maka UUPK membuka kemungkinan bagi konsumen yang mengalami kerugian akibat mengkonsumsi produk obat kuat impor untuk meminta pertanggungjawaban kepada importir produk obat tersebut. ${ }^{19}$

Namun, oleh karena terdapat beberapa produk obat tersebut beredar secara ilegal di Indonesia dengan cara diselundupkan oleh importir yang tidak memiliki izin, maka menurut Bapak Dr. Ermanto Fahamsyah, S.H.,M.H., tidak ada pelaku usaha yang bertindak sebagai importir produk tersebut. ${ }^{20}$ Oleh karena itu, tidak ada importir yang dapat diminta pertanggungjawabannya oleh konsumen yang mengalami kerugian akibat mengkonsumsi produk obat kuat impor tersebut. Dalam hal ini, oleh karena obat kuat impor tersebut dimasukkan ke dalam wilayah Indonesia secara ilegal, sehingga tidak ada agen ataupun kantor

\footnotetext{
${ }^{18}$ Dr. Ermanto Fahamsyah, S.H.,M.H., Hasil wawancara

${ }^{19}$ Indonesia, Kitab Undang-Undang No. 8 Tahun 1999 tentang Perlindungan Konsumen, op. cit., Pasal. 21 ayat (1).

${ }^{20}$ Bapak Dr. Ermanto Fahamsyah, S.H.,M.H., Op. Cit.,
} 
perwakilan ataupun importir yang dapat diminta pertanggungjawabannya oleh konsumen, maka konsumen yang telah mengalami kerugian akibat menggunakan atau mengkonsumsi obat kuat impor tetap dapat meminta pertanggungjawaban pada pelaku usaha yang memperdagangkan obat kuat impor tersebut.

Terdapat beberapa pengaturan pasal didalam ketentuan UUPK yang dilanggar oleh para pelaku usaha yang mengedarkan ataupun menjual produk obat kuat impor, berdasarkan ketentuan Pasal 8 ayat (1) huruf $\mathrm{d}$, e, f, dan j. Pada intinya pengaturan pasal tersebut mengatur mengenai perbuatan yang dilarang bagi pelaku usaha. Berdasarkan ketentuan Pasal 8 ayat (1) huruf d UUPK yang mengatur mengenai larangan bagi pelaku usaha untuk memperdagangkan barang dan/atau jasa yang tidak sesuai dengan kondisi, jaminan, keistimewaan atau kemanjuran sebagaimana dinyatakan dalam label, etiket atau keterangan barang dan/atau jasa tersebut. ${ }^{21}$ Dalam ketentuan pasal tersebut mempertegas bahwa para pelaku usaha jelas telah mengetahui bahwa obat kuat impor yang diperdagangkan mengandung zat aktif BKO yang hanya mempunyai keistimewaan atau kemajuran bagi konsumen penderita DE saja, tetapi tidak terhadap konsumen pada umumnya. Kemudian, berdasarkan ketentuan pasal 8 ayat (1) huruf e UUPK yang mengatur mengenai larangan bagi para pelaku usaha untuk memperdagangkan barang dan/atau jasa yang tidak sesuai dengan mutu, tingkatan, komposisi, proses pengolahan, gaya, mode, atau penggunaan tertentu sebagaimana dinyatakan dalam label atau keterangan barang dan/atau jasa tersebut. ${ }^{22}$ Selain itu, berdasarkan ketentuan Pasal 8 ayat (1) huruf f UUPK yang mengatur mengenai larangan bagi para pelaku usaha untuk memperdagangkan barang dan/atau jasa yang tidak sesuai dengan janji yang dinyatakan dalam label, etiket, keterangan, iklan atau promosi

${ }^{21}$ Indonesia, Kitab Undang-Undang No. 8 Tahun 1999 tentang Perlindungan Konsumen, op. cit., Pasal 8 ayat (1) butir d.

${ }^{22}$ Ibid., Pasal 8 ayat (1) butir e. 
penjualan barang dan/atau jasa tersebut. ${ }^{23}$ Selain itu, berdasarkan ketentuan Pasal 8 ayat (1) huruf j UUPK yang mengatur mengenai mengenai larangan bagi pelaku usaha untuk memperdagangkan barang dan/atau jasa yang tidak mencantumkan informasi dan/atau petunjuk penggunaan barang dalam bahasa Indonesia sesuai dengan ketentuan perundang-undangan. ${ }^{24}$

Apabila terdapat konsumen mengalami kerugian akibat mengkonsumsi obat kuat impor, oleh karena pelaku usaha melanggar ketentuan Pasal 8 ayat (1) huruf d, e, f, dan j UUPK, maka terdapat 2 (dua) macam bentuk penyelesaian sengketa yang diatur dalam ketentuan Pasal 47 UUPK, yaitu melalui jalur pengadilan maupun melalui jalur non pengadilan yang diselenggarakan untuk mencapai kesepakatan mengenai bentuk dan besarnya ganti rugi dan/atau mengenai tindakan tertentu untuk menjamin tidak akan terjadinya kembali kerugian yang diderita oleh konsumen. ${ }^{25}$ Penyelesaian sengketa konsumen dapat dilakukan alternatif resolusi masalah ke BPSK, LPKSM, Direktorat Perlindungan Konsumen di bawah Departemen Perdagangan, atau lembaga-lembaga lain yang berwenang. Namun, dengan adanya pengaturan dalam ketentuan Pasal 19 ayat (1) yang mengatur bahwa pelaku usaha bertanggung jawab memberikan ganti rugi atas kerusakan, pencemaran, dan/atau kerugian konsumen akibat mengkonsumsi barang dan/atau jasa yang dihasilkan atau diperdagangkan. ${ }^{26}$ Maka terdapat 1 (satu) pelaku usaha yang sudah pasti dapat diminta pertanggungjawabannya oleh konsumen yang telah mengalami kerugian akibat mengkonsumsi obat kuat impor.

Berdasarkan pengaturan tersebut, walaupun obat kuat impor tersebut dislundupkan ke dalam wilayah Indonesia secara ilegal, sehingga tidak ada agen ataupun kantor perwakilan ataupun importer yang dapat

\footnotetext{
${ }^{23}$ Ibid., Pasal 8 ayat (1) butir f.

${ }^{24}$ Ibid., Pasal 8 ayat (1) butir j.

25 Ibid. Pasal 47.

${ }^{26}$ Ibid, Pasal 19 ayat (1).
} 
dimintai pertanggungjawaban oleh konsumen, maka konsumen yang telah mengalami kerugian akibat mengkonsumsi obat kuat impor tersebut tetap dapat menggugat pelaku usaha yang memperdagangkan obat tersebut kepada yang bersangkutan. Hal tersebut dapat disesuaikan dengan pendapat dari Bapak Dr. Ermanto Fahamsyah, S.H.,M.H, yang menyatakan bahwa berdasarkan ketentuan dari Pasal 19 ayat (1) UUPK, bahwa pelaku usaha atau pedagang eceran obat yang memperdagangkan obat kuat impor tersebut bertanggung jawab untuk memberikan ganti rugi kepada konsumen yang telah membeli obat ilegal tersebut dari mereka, yang kemudian mengalami kerugian akibat mengkonsumsi obat kuat impor tersebut. ${ }^{27}$ Maka dengan demikian, sesuai ketentuan Pasal 19 ayat (1) UUPK, bahwa pelaku usaha yang memperdagangkan obat kuat impor ilegal merupakan pihak yang tepat untuk digugat oleh konsumen dan bertanggung jawab atas kerugian akibat mengkonsumsi obat tersebut yang telah mereka beli dari pelaku usaha yang bersangkutan. Dasar gugatan konsumen yang mengalami kerugian akibat mengkonsumsi produk obat kuat impor tanpa izin edar merupakan Perbuatan Melawan Hukum (PMH) yang telah dilanggar oleh para pelaku usaha sebagaimana diatur di dalam UUPK. Selain itu, dalam ketentuan Pasal 45 ayat (3) UUPK menyatakan bahwa penyelesaian sengketa di luar pengadilan sebagaimana dimaksud dalam ketentuan Pasal 45 ayat (2) UUPK, tidak menghilangkan tanggung jawab pidana sebagaimana diatur dalam undang-undang. ${ }^{28}$ Maka dengan demikian dasar hukum yang dapat digunakan oleh konsumen sebagai bentuk pertanggungjawaban yang ditujukan kepada pelaku usaha atau pedagang eceran obat ilegal tersebut merupakan sanksi pidana sebagaimana diatur dalam ketentuan Pasal 62 ayat (1) UUPK, yang menjelaskan bahwa bagi pelaku usaha yang melanggar ketentuan sebagaimana dimaksud dapat dikenakan sanksi

\footnotetext{
${ }^{27}$ Bapak Dr. Ermanto Fahamsyah, S.H.,M.H., Op. Cit.,

${ }^{28}$ Indonesia, Kitab Undang-Undang No. 8 Tahun 1999 tentang Perlindungan Konsumen, op. cit., Pasal 45 ayat (3).
} 
pidana berdasarkan ketentuan Pasal 8, Pasal 9, Pasal 10, Pasal 13 ayat (2), Pasal 15, Pasal 17 ayat (1) huruf a, huruf b, huruf c, huruf e, Pasal 17 ayat (2), dan Pasal 18, dan dapat dipidana dengan pidana penjara paling lama 5 (lima) tahun atau pidana denda paling banyak Rp 2.000.000.000,(dua milyar rupiah). Dalam hal ini, apabila terhadap pelanggaran yang telah dilakukan oleh pelaku usaha mengakibatkan cedera berat, luka berat, sakit berat, cacat tetap atau bahkan kematian maka diberlakukan ketentuan pidana yang berlaku dalam Kitab Undang-Undang Hukum Pidana. Selain sanksi pidana pokok yang dapat diberikan, terdapat sanksi tambahan yang dapat dijatuhkan kepada pelaku usaha berdasarkan ketentuan Pasal 62 UUPK, antara lain: ${ }^{29}$

1. Perampasan barang tertentu.

2. Pengumuman keputusan hakim.

3. Pembayaran ganti rugi.

4. Perintah penghentian kegiatan tertentu yang menyebabkan timbulnya kerugian konsumen.

5. Kewajiban penarikan barang dari peredaran atau

6. Pencabutan izin usaha.

\section{PENUTUP}

\section{A. Kesimpulan}

Dari pembahasan yang telah diuraikan mengenai kegiatan perlindungan konsumen yang berhubungan dengan pelangaran hukum yang dilakukan pelaku usaha terkait dengan peredaran produk obat kuat impor dan tanggungjawab pelaku usaha terhadap konsumen yang mengalami kerugian akibat mengkonsumsi obat kuat impor yaitu bahwa pelaku usaha obat kuat impor dalam memperdagangkan produknya telah melanggar beberapa ketentuan hukum yang telah diatur dalam Pasal 4 huruf a dan c, Pasal 7 huruf a, b, dan d, Pasal 8 ayat (1) huruf d, e, f, dan j, Pasal 9 huruf c, I, dan k, Pasal 10 huruf c, i, dan k Undang-Undang

${ }^{29}$ Ibid., Pasal 63. 
Nomor 8 Tahun 1999 tentang Perlindungan Konsumen. Pasal 98 ayat (2), Pasal 106 ayat (1) dan ayat (2) Undang-Undang Nomor 36 Tahun 2009 tentang Kesehatan. Pasal 2 ayat (2) dan Pasal 4 Keputusan Menteri Kesehatan nomor 1331 Tahun 2002 tentang Pedagang Eceran Obat. Pasal 2 dan Pasal 3 Peraturan Kepala Badan Pengawas Obat dan Makanan Nomor HK.00.05.1.3459 Tentang Pengawasan Pemasukan Obat Import. Pelaku usaha yang bertanggung jawab terhadap konsumen apabila obat kuat impor tersebut dimasukkan ke dalam wilayah Indonesia secara illegal atau tanpa izin edar yang diperoleh bukan melalui agen maupun kantor perwakilan ataupun importir yang dapat diminta pertanggungjawabannya, maka konsumen tetap dapat meminta pertanggung jawaban kepada pedagang eceran atau pelaku usaha yang yang memperdagangkan obat kuat impor tersebut, sesuai ketentuan Pasal 19 ayat (1) UUPK. Tanggungjawab pelaku usaha terhadap konsumen yang mengalami kerugian akibat mengkonsumsi obat kuat import, antara lain: 1. Pelaku usaha bertanggungjawab memberikan ganti rugi atas kerusakan, pencemaran, dan/atau kerugian konsumen akibat mengkonsumsi barang dan/atau jasa yang dihasilkan atau diperdagangkan. Maka pelaku usaha yang memperdagangkan produk obat kuat impor tanpa izin edar tersebut sebagai pihak yang tepat untuk digugat oleh konsumen yang mengalami kerugian. Dasar gugatan konsumen yang mengalami kerugian akibat mengkonsumsi produk obat kuat impor ilegal merupakan Perbuatan Melawan Hukum (PMH) yang dilakukan oleh pelaku usaha sebagaimana diatur di dalam Pasal 19 ayat (1) UUPK. 2. Pelaku usaha juga dapat dikenakan sanksi pidana karena melanggar ketentuan sebagaimana diatur dalam Pasal 8, Pasal 9, Pasal 10, Pasal 13 ayat (2), Pasal 15, Pasal 17 ayat (1) huruf a, huruf b, huruf c, huruf e, Pasal 17 ayat (2), dan Pasal 18, dapat dipidana dengan pidana penjara paling lama 5 (lima) tahun atau pidana denda paling banyak Rp 2.000.000.000,- (dua milyar rupiah). Maka dengan demikian dasar hukum yang digunakan konsumen sebagai bentuk pertanggungjawaban 
yang ditujukan kepada pelaku usaha atau pedagang eceran obat ilegal tersebut merupakan sanksi pidana sebagaimana di atur berdasarkan Pasal 62 ayat (1) UUPK.

\section{B. Saran}

Pelaku usaha yang melanggar peraturan perundang-undangan yang berlaku seharusnya ditindaklanjuti lebih tegas lagi. Karena hingga saat ini, sanksi yang diterapkan oleh BPOM hanya berupa sanksi administratif, sehingga belum dapat memberikan efek jera terhadap para pelaku usaha. Selain itu, pelaku usaha harus mematuhi peraturan yang telah dibuat dan diberlakukan dalam menjalankan kegiatan usahanya, terutama mengenai izin edar yang sudah ditetapkan oleh BPOM. Masyarakat sebagai pengguna atau konsumen harus lebih cermat dan teliti dalam memperoleh suatu informasi mengenai produk yang akan dikonsumsinya, apabila diketahui adanya obat kuat impor yang mencurigakan atau tidak terdaftar di BPOM maka segera membuat pengaduan terhadap produk tersebut. Karena dengan adanya laporan dari masyarakat BPOM dapat bertindak langsung terhadap para pihak yang beritikad tidak baik dalam menjalankan usahanya. Perlu adanya pengetahuan lanjutan kepada masyarakat mengenai obat-obatan yang dapat dikonsumsi secara aman dan telah memiliki hasil lulus uji dari BPOM.

\section{DAFTAR PUSTAKA}

\section{A. BUKU}

Hanitijo, Soemitro Ronny. Metode Penelitian Hukum dan Yurimetri. (Jakarta: Ghalia Indonesia, 1988).

Marzuki, Peter Mahmud. Penelitian Hukum. (Jakarta: Kencana Prenada Media Group, 2005).

Nasution, Bahder. Sistem Hukum. (Jakarta: PT Rineka Cipta, 2005). 
Nugroho, Susanti Adi. Proses Penyelesaian Sengketa Konsumen Ditinjau dari Hukum Acara Serta Kendala Implementasinya. Cetakan ke-1. (Jakarta: Kencana, 2008).

\section{B. UNDANG-UNDANG}

Indonesia. Kitab Undang-Undang nomor 8 Tahun 1999 tentang Perlindungan Konsumen.

Putusan Mahkamah Agung Republik Indonesia Putusan Nomor: 33/ Pid.Su / 2013 / PN. Kdr.

Keputusan Menteri Kesehatan Nomor 1331/MENKES/SK/X/2002 Tahun 2002 tentang Pedagang Eceran Obat Pasal 2 ayat (2).

C. WIBESITE

Mashudi, Didik. "Toko Obat Kuat Tanpa Izin Digrebek Polisi". http://m.tribunnews.com/regional/2012/12/13/toko-obat-kuattanpa-izin-digrebek-polisi diakses 15 Maret 2018.

Nugroho, Adi. "Diduga overdosis obat kuat, pria paruh baya Bekasi tewas dikamar PSK". http://m.merdeka.com/peristiwa/diduga-overdosisobat-kuat-pria-paruh-baya-bekasi-tewas-di-kamar-psk.html, diakses 03 Agustus 2018. 